\title{
African language books for children: issues for authors
}

\section{Article}

Accepted Version

Edwards, V. and Ngwaru, J. M. (2012) African language books for children: issues for authors. Language, Culture and Curriculum, 25 (2). pp. 123-137. ISSN 1747-7573 doi: https://doi.org/10.1080/07908318.2011.629051 Available at https://centaur.reading.ac.uk/24766/

It is advisable to refer to the publisher's version if you intend to cite from the work. See Guidance on citing.

To link to this article DOI: http://dx.doi.org/10.1080/07908318.2011.629051

Publisher: Taylor \& Francis

All outputs in CentAUR are protected by Intellectual Property Rights law, including copyright law. Copyright and IPR is retained by the creators or other copyright holders. Terms and conditions for use of this material are defined in the End User Agreement.

\section{www.reading.ac.uk/centaur}

\section{CentAUR}

Central Archive at the University of Reading

Reading's research outputs online 


\title{
African language books for children: issues for authors
}

\author{
Viv Edwards \\ University of Reading
}

Marriote Ngwaru

Aga Khan University Institute for Educational Development, Dar es Salam

\begin{abstract}
Growing interest in bilingual education in Sub-Saharan Africa has highlighted the urgent need for reading material in African languages. In this paper, we focus on authors, one of several groups of stakeholders in the publishing industry with responsibility for meeting this demand. In order to provide a context for the discussion, we briefly survey the history of children's literature in Africa and approaches to literacy teaching which address a perennial complaint of African educators: the absence of a culture of reading. We then address three main questions: What is the nature and extent of African language publishing for children? What are the challenges for authors writing for children in African languages? And what measures are being taken to support authors wishing to write for children in African languages? Our analysis is based on interviews and focus group discussions with publishers, authors, translators, educationalists and representatives of book promotion organizations from nine African countries and documentary data on children's books in African languages. While there are indications of a growing commitment to producing books for children in local languages, the number of titles is constrained by funding and falls short of actual need. The main challenges for authors are two-fold: the need to understand the ingredients for successful children's books; and the sensitivity to negotiate the linguistic challenges associated with a newly emergent genre in African languages. Very few aspiring authors meet either criterion. The most common forms of support for aspiring authors are competitions and workshops, often offered by publishers interested in generating stories for publication. While such initiatives - and particularly the workshops - are to be commended, they are also problematic: often they are reliant on external funding and expertise and offer only temporary solutions. We finish with suggestions for more sustainable ways forward.
\end{abstract}




\section{African language books for children: issues for authors}

\section{Introduction}

Arguments about which languages should be used as the medium of instruction in African schools are both volatile and vacillating. In pre-colonial times, missionaries, whose prime concern was saving souls (and therefore ensuring good communication), expended considerable energy on developing orthographies for the local languages used in their schools. Later, European languages became a vital tool in the formation of the local elites who assisted in implementing the colonial vision for Africa. In the years since independence, various reasons have been advanced for the continued use of the former colonial languages, including their relative neutrality in highly multilingual settings and the economic benefits of delivering education in one language.

Increasingly, however, counterarguments have been gathering momentum, spearheaded by evidence of the very poor academic achievements of children educated through a language to which most had very little exposure outside the classroom. Ambatchew (2004), for instance, reports that very few students in Grade 8 government schools in Addis Ababa had adequate reading skills in English. Similar patterns have been reported in South Africa where Heugh (2007) links the slow implementation of mother-tongue-based bilingual education with falling levels of literacy and academic performance. The overwhelming consensus of linguists and educators is that bilingual education better reflects what Alidouet al.(2006: 10) describe as 'the socioeconomic and cultural realities of multilingual Africa' (Baker 2011). Possibly motivated by the desire to defend their elite status as speakers of European languages and the power they bestow, politicians are more ambivalent (Trudell, 2010).Ghana is a case in point: Owu-Ewie (2006) documents how the languagein-education policy at the lower primary level changed five times between independence and the time of writing.

Nonetheless, there is growing interest in the use of 'mother-tongue-based bilingual education"1 in countries such as Mali, Mozambique and South Africa. The challenges for governments wishing to experiment with or implement bilingual policies include the training of teachers in appropriate pedagogies and the dearth of learning materials in African languages. In this paper, we focus, in particular, on the latter. Materials development is a complex issue, involving a wide range of 
stakeholders, including publishers, educationalists, writers and translators. As part of a project on Interdisciplinary perspectives on African language materials for children, we have reported elsewhere on the role of translators (Edwards \& Ngwaru, 2010) and publishers (Edwards \& Ngwaru, in press). Our present focus is on the challenges for authors of African language materials and particularly those aimed at children aged 0-11.

\section{African language and literature}

The first African language literature was essentially oral; its influence is still apparent today. Authors such as Buchi Emecheta claim that the seeds of their writing careers were sewn 'at the feet of the tellers of folktales, and the tales came to be the base for their launching into the world of story - oral or written' (Osa, 2007). During the colonial period, literature was imported from Europe with the aim of promoting Christianity and 'civilization' (O'Sullivan, 2005). Most children's books in this period were either textbooks or imported books promoting a colonial perspective. One of the underlying messages of formal schooling is that written literature is 'mature, civilized, and conscious of its art'; oral literature in contrast, is viewed as 'primitive and lacking in technique' (Osaki 2004). The association of written literature with European languages has further served to reinforce the low status of African languages.

Following independence the focus was on developing indigenous written literature, with leading figures such as Chinua Achebe appealing to African authors and illustrators to save African children from the 'beautifully packaged poisons' imported from Europe (Gregorio, 2001: 15). Views on the languages in which these books should be written, however, are highly polarized. Although Achebe (1975) acknowledges that abandoning one's mother tongue is a 'dreadful betrayal' that produces 'a guilty feeling', he argues that for him there was no other choice: 'I have been given a language and I intend to use it'. In contrast, Ngũgĩ wa Thiong'o (1988) describes his decision to start writing in Gikuyu after seventeen years of involvement in Afro-English literature as 'part and parcel of the anti-imperialist struggles of Kenyan and African peoples'. Nonetheless, growing numbers of multilingual and indigenous publications are helping to create a clearly African identity in the postindependence period. 


\section{Materials for literacy learning}

Any discussion of the issues facing authors of children's books in African languages can usefully be prefaced by a consideration of both the role of literacy in development and the theories that underpin literacy teaching. A literate population is fundamental to economic progress; educationalists also point to the socio-psychological benefits of literacy, including self-esteem, confidence, personal empowerment and increased civic engagement (UNESCO, 2005). It is thus a matter of concern that, although the proportion of school enrollments is rising rapidly and the gender gap is slowly narrowing, literacy rates in sub-Saharan Africa remain low, with significant disparities between - and within - rural and urban areas.

Dissatisfaction with educational outcomes has inevitably led to a reappraisal of teaching methods. Traditionally, literacy was seen as a set of discrete skills to be acquired and orchestrated through decontextualized exercises designed to offer opportunities for practice (Bloch 1999, Edwards, 2009). More recently, there has been a move in policy and curriculum documents at the international level to include notions of social constructivist approaches which children to behave like readers and writers in order to learn, read and produce real and meaningful texts. The same principles applied to African contexts logically require the use of local languages which allow children to use their knowledge of life and language to make meaning of, rather than simply decoding, the text.

Although the impact of these policy changes in African classrooms is minimal, incipient changes in pedagogy are beginning to be reflected in the materials used in classrooms. Our interest in this paper is on materials that relate to literacy rather than to other areas of the curriculum. In Africa, textbooks related to literacy learning take the form of workbooks and readers. Increasingly, however, 'supplementary materials' (to use the African terminology) or 'real books' (the term most commonly used in North America, the UK, Australia and New Zealand) are found alongside textbooks. Real books are well-produced, attractive stories that avoid the weaknesses of the artificial language of the 'readers', constructed to teach key vocabulary or particular sounds to children. 
The absence of a culture of reading is seen as playing an important role in the low levels of literacy (Bloch, 2006). It is widely believed that one of the consequences of the heavy reliance on materials that have little or no relevance for everyday life is that very few children are equipped or motivated to read either for pleasure or information by the end of formal schooling. Yet, when reading is presented as interesting, achievable and, above all fun, the findings of international research (see, for instance, Clark \& Rumbold, 2006) suggest that children are more likely to choose to read. In this view, the more children read, the more proficient they become; the more literate they are, the better the educational outcomes. Developing an understanding of the most effective ways of promoting a culture of reading is thus an important priority.

The enthusiasm with which real books are embraced varies a great deal from one African country to another. In Ethiopia, Ambatchew (2005) bemoans the limited understanding of the role books play in children's psycho-social development: 'It is the characters in storybooks that provide children with their heroes and villains and shape their outlook towards life'. A symptom of this limited official understanding is the measurement of progress towards the goals of the Convention on the Rights of the Child (CRC) in terms of increased number of textbooks, rather than real books. The main thrust for the use of real books thus comes from non-governmental organizations (NGOs), such as CODE Ethiopia and the Ethiopian Books for Children and Educational Foundation, rather than state schools though there are signs of change here, too. Ambatchew (2004) describes library clubs in Ethiopian secondary schools, where members are given borrowing privileges and encourage their peers to use the library as 'more than a quiet place to do their homework'.

Activists in Tanzania also attach importance to reading for enjoyment. One of the outcomes claimed for the Children's Book Project, set up in 1991 in response to the acute shortage of books for children, is the integration of reading activities into the daily lives of children and community members. The vision of the project is 'to develop a strong reading culture amongst Tanzanian school children'.

NGOs committed to reading promotion, such as PRAESA, READ, Room to Read and Biblionef, are also very much in evidence in South Africa. However, the use of real books also enjoys official support in the form of national and provincial book promotion campaigns, such as the 100 books in every classroom and the staging of a National Book Week (Edwards \& Ngwaru, 2010). Grassroots 
support for reading for enjoyment is also evident. The Vulindlela reading clubs in Cape Town (organized by PRAESA and run by volunteers) regularly attract large numbers of children. The aim is to create an atmosphere very different from school. The Saturday morning sessions start with circle games and singing; children then divide into three different age-related groups to listen to stories and to stretch out or cuddle up with a book (see http://www.littlehandstrust.com/videos.html) In short, while traditional didactic approaches prevails across the continent, there is a growing recognition of the need to promote reading for enjoyment.

\section{Methodology}

In this paper, we address three main questions: (1) What is the nature and extent of African language publishing for children? (2) What are the challenges for authors writing for children in African languages? And (3) what measures are being taken to support authors wishing to write for children in African languages?

Our study is based on data from a two-part study on African language materials for children: a case study of African language publishing in South Africa; and an evaluation of Stories across Africa, a pan-African storybook development project. ${ }^{2}$ We assembled documentary evidence on African language books for children and were able to observe one of the writers' workshops organized by Stories Across Africa. Finally we undertook interviews and facilitated focus group discussions at two meetings (one in Reading, UK, the other in Cape Town) which brought together publishers, authors, translators, educationalists and representatives of book promotion organizations from Egypt, Ethiopia, Ghana, Kenya, Mali, Nigeria, Rwanda, Tanzania and South Africa. Some 40 hours of interview and focus group discussions were transcribed and analyzed using HyperResearch, a cross platform qualitative data analysis package.

It needs to be explained at the outset in relation to the first of our research questions - the nature and extent of African language publishing for children - that statistics on publishing in Africa are, for the most part, unreliable, incomplete or non-existent. South Africa, which boasts a world class publishing industry, supported by PASA (Publishers' Association of South Africa) and SABDC (the 
South African Book Development Council), is a notable exception. Yet even here the data are incomplete for our purposes: the industry annual review (Galloway et al., 2009), for instance, offers information on breakdown by language for the trade market ${ }^{3}$, but fails to differentiate between children's books and books for adults. However, recently produced catalogues of children's books in African languages (PASA 2007, 2008, 2009; DAC, 2008) made it possible for us to undertake our own analysis (Edwards \& Ngwaru, 2010), at least in relation to South Africa. The documentary data were supplemented by information on other African countries gathered in interviews and focus groups and hard to access material ${ }^{4}$ drawn to our attention by participants.

Information relating to the remaining two questions - the challenges for authors writing for children in African languages and the measures being taken to support them - was extracted from the interview and focus group discussions.

\section{African language provision}

While there is consensus, at least in the early years of education, about the usefulness of real books in the promotion of a culture of reading and the role of African languages in this process, the question remains as to the availability of African language books for children.

Tanzania, one of only two African states that adopted an African language as the official language on independence, is understandably committed to publishing in Kiswahili. The Children's Book project has produced well over 200 titles since it was established in 1991; it has not proved possible, however, to locate data on other initiatives from published sources.

Ethiopia is the other country. Amharic is the most widely spoken language, used in government, by the army and in the Ethiopian Orthodox Church since medieval times, though it has been replaced in many areas of the country by local languages. Some 15 languages are currently used as the medium of instruction in schools. Three main groups are involved in publishing books for children in local languages: traditional book distributors such as Education Materials Production and Distribution Enterprise; multinationals such as Cambridge University Press, Oxford University Press and Macmillan; and non-government organizations (NGOs), such as CODE Ethiopia (Ambatchew, 
2008). The total number of books in Amharic is estimated to be in the region of 300 , of which perhaps two dozen are in print at any given time (Abebe \& Lemma, 1997). The number of children's books in any language is also small and, according to Tesfaye (2004), less than a hundred; of those written in African languages, most are in Amharic.

By far the most detailed country specific picture, however, is provided by the Interdisciplinary Perspectives on African Language Materials for Children Project (Edwards \& Ngwaru, 2010, 2011). This analysis is based on two main sources: the 2007 PASA (Publishers' Association of South Africa) Writing in Nine Tongues ${ }^{5}$ catalogue and its 2008 and 2009 supplements; and the 2008 Catalogue of South African Literature published by the Department of Arts and Culture. Writing in Nine Tongues includes well over 5000 different titles in isiNdebele, isiXhosa, isiZulu, Sesotho, Sepedi, Setswana, SiSwati, Tshivenda and Xitsonga. The Catalogue of South African Literature (DAC 2008) includes almost 4000 titles, many of which overlap with Writing in Nine Tongues. However, its coverage is wider: listings are also in English, Afrikaans and Khoi San.

While publishing in African languages in South Africa might seem at first sight to be vibrant, it is important to look beyond the total numbers of books included in these catalogues. For instance, although most of the titles have been published since 2005, they include output over a much longer time period. In addition, they are divided among nine languages in the case of Writing in nine tongues and twelve languages in the case of the Catalogue of South African Literature. The numbers of books available in any given language are much more limited.

A recurrent issue in discussion of African language publishing in South Africa is whether books are originated in the African language or translated from English. While the majority of books aimed at older students are indeed originated in African languages, many of the picture books are 'readers' targeted at young children are indeed translations (Bloch 2000; Kruger, 2009). Some observers are critical of this trend, arguing that it has a detrimental effect on the development of original writing; others feel that the main issue is to ensure that children have access to a wide range of reading material in African languages and feel that translation offers one means to this end. Still others point out the important role played by children's literature in Europe, making accessible to wide audiences works such as Aesop's fables and the works of the bothers Grimm translation; they 
argue that similar benefits will accrue when African readers have access to translated stories (Bloch, 2011, personal communication)

The numbers of books available vary considerably from language to language, mirroring the composition of the population as a whole. Figure 1, based on analyses of the 2007 Writing in ninetongues catalogue and the 2008 supplement, clearly shows this pattern.

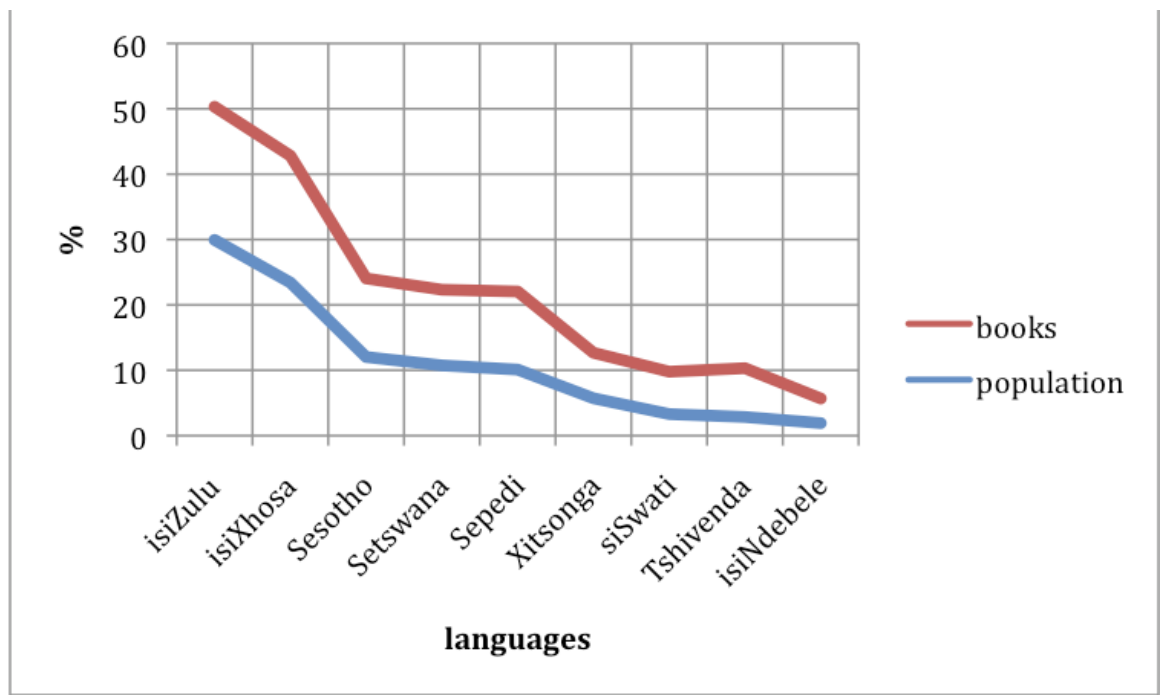

Figure 1: Proportion of books in African languages by population

One of the defining characteristics of publishing for children across Africa is the very heavy dependence on the schools market (Wafawarowa, 2006; OECD 2008: 178). As shown in Figures 3 and 4, South Africa is no exception to this trend. 


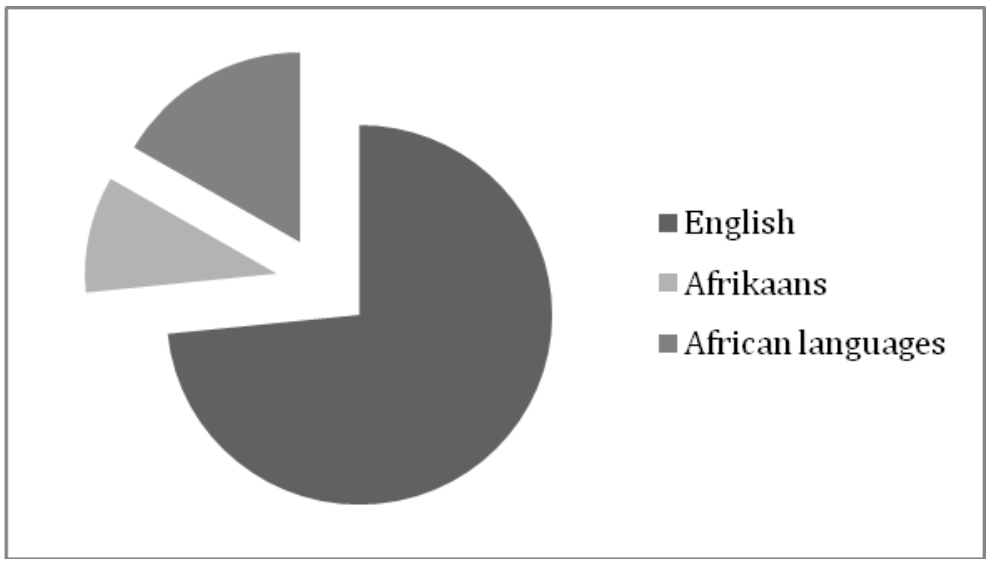

Figure 3: Net turnover of local book sales to schools according to language

[Source: Galloway et al., 2009]

English books make up $73.2 \%$ of sales to schools despite the fact that English is spoken as a first language by only $8.2 \%$ of the population. This compares with $9.89 \%$ of sales of Afrikaans, spoken by $13.3 \%$ of the population, and $16.62 \%$ of sales of the other African languages combined, speakers of which make up $78.5 \%$ of South Africans. However, when we look at the number of titles produced for the schools market by publishers providing data on language (Figure 4), the picture becomes rather more complex.

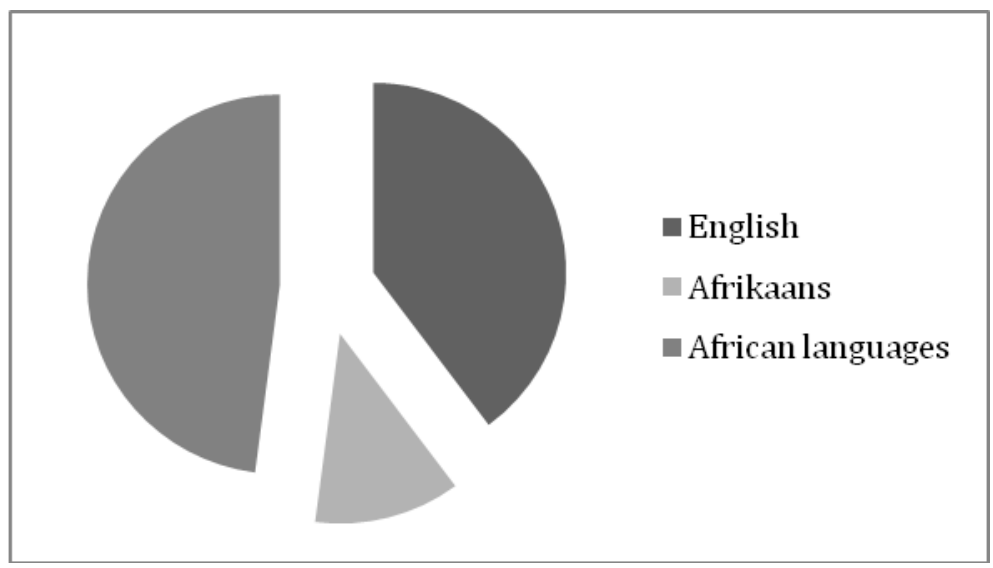

Figure 4: Title production for the education sub-market by language Source:Galloway et al. 2009). 
African language books in 2007 made up the largest number of new titles (47.92\%), followed by English (39.77\%) and Afrikaans (12.31\%). This higher proportion of African language titles may suggest awareness on the part of publishers of the economic importance of a market supported, in principle at least, by the government policy of mutilingualism.

\section{Challenges for writers}

While the drive to produce more titles in African languages offers new opportunities for local writers, it also creates new challenges. Very few African authors write in their first languages; most manuscripts submitted to publishers are in English and, in the view of all the publishers we interviewed, tend to be of very poor quality. Prospective authors of children's books face a double challenge: developing the skills required for producing books that will appeal to children; and working in a language where the genre specific norms are still evolving.

\section{Writing for children}

I once heard the statement "Writing children books is a lot easier than writing novels and other books." I cringed and thought to myself, the opposite is true. Unfortunately this is the sentiment of many people who are not familiar with what it takes to write an engaging book for children. (Weaver, 2010)

Nicole Weaver's (2010) is not alone in her irritation with common misconceptions about writing for children. All the writers consulted in the course of this study shared her views.

Two main trends can be detected in real books for children in post independence Africa - oral retellings of folk tales and narrative fiction (Khorana, 1998). In the context of narrative fiction, an important consideration for many for children's authors is the accurate depiction of a full range of experiences, rural and urban. Commenting on the story she was developing, one of the participants in the writing workshop summed up the challenge thus: 
Traditional stories provide the history of our lives and how our lives have evolved from one generation to another. So if I a child asked me: 'What did my grandmother do when she grew up?' then those stories would allow me to explain that life to my child. But she would still have the modern stories... When I grew up in the Eastern Cape I felt like I was really in an African world. But living now in urban areas my world has broadened ... So in this story I show a child driving his car made of wire because this is what children in the rural areas used to do, but I'm also moving out beyond that and saying that we have aeroplanes and cars that are common to children living in these other worlds. Trying to bridge that gap is the most exciting thing for me...

The universal appeal of folktales is also apparent in books for children. Given the strong oral tradition in Africa, it might be assumed that such retellings would be unproblematic. However, story telling and story writing require very different skills. As Pellowski (1980: 60) points out:

Transferring oral materials and editing them requires just as much work as writing new materials, in order to be completely successful. In all too many countries, such folklore (in versions for children) has been put down haphazardly, carelessly and with little regard for the requirements of written forms of the literature.

There are other challenges peculiar to children's literature, too. Picture books, for example, require a sophisticated understanding of the interaction between text and illustration. In this genre, the overall story is constrained by the number of pages available (multiples of eight and, usually, 24 or 32) and the text must 'talk' to the pictures on the same page. Writers therefore need to think visually. Because picture books are most often read aloud, there are also oral requirements. The aim, then, is to achieve a 'rhythmic totality of performance' (Oittinen, 2003), taking into account sentence length, punctuation, page openings and turnings.

For many aspiring authors, the challenge is neither imagination nor shortage of ideas for stories but the need for practice and support in developing the necessary skills. In the words of another of the writing workshop participants: 
It sounds easy but it's difficult because I have things flowing in my head but I don't know how to put them on paper. I talk too much and tend to be like that with my writing as well. I don't know how to hone it down.

\section{Writing in African languages}

There is no shortage of either aspiring authors or books advising them on how to achieve their ambitions (see, for instance, Dils, 1998; Shepherd, 2000). This advice often focuses on the kind of language that works best in children's books, including sentence length, stress and rhythm. However, we have been unable to locate any discussion of the extent to which these prescriptions are language specific or more general. The experience of the Early Literacy Unit at PRAESA in producing English and IsiXhosa versions of an African version of Pinocchio is interesting in this respect.

The starting point was agreement that Pinocchio was a text that African language speaking South African children would relate to. It was then decided to 'retell' the story in Xhosa, rather than to do a translation of the English version. A team of one English speaking project manager and three Xhosa writers began by reading an old English translation of Pinocchio. The writers then stripped the story to its bare bones in isiXhosa. The challenges encompassed both discourse features and the conceptual framing of a story - in which the European fairy godmother was transformed into an elder, while the three wise men trying to heal Pinocchio become a sangoma, a traditional healer and a modern doctor. Once the first Xhosa draft was written, it was roughly translated into English , and passed on to an established English language author to create an English version. This initially failed to flow well, and needed further intervention by another author to achieve the metaphor, and variety in rhythm associated with successful children's books in English. The illustrations were then commissioned using the English version; when these were received, final changes were made to the Xhosa version to ensure that harmony was achieved between the Xhosa and the English text as well as both texts and illustrations. There are various possible explanations for the mismatch between the early isiXhosa and English versions. It could be argued, for instance, that the discourse of children's books in isiXhosa is at a relatively early stage of development, or that the isiXhosa- 
speaking members of the team were relatively inexperienced in writing for children. The project was a lengthy one, extending over two years, partly because of the other work commitments of the team, partly because they were writing as a committee and partly because they were new and inexperienced writers.

The issue of the standardization of African languages - or indeed any other languages recently committed to writing - also needs to be considered. Two competing trends can be detected in African linguistics: diversification and homogenization. Writers who emphasize diversity estimate that some 2000 or so languages are spoken in Africa. In contrast, advocates of homogenization contend that 75 to 80 percent of all sub-Saharan Africans speak one of twelve root languages (Prah, 2009). Both positions have implications for children's publishing.

A historical perspective is required to explain the current situation. Competition among missionaries who developed the various orthographies led to the arbitrary fragmentation of the linguistic landscape: instead of having one Nguni language, South Africans today consider isiZulu, isXhosa, SiSwati, and isiNdebele to be separate languages; similarly, Setswana, Sepedi, and Sesotho are treated as distinct rather than as varieties of Sotho. The publishers we interviewed for the South African case study were very aware of the resulting tensions:

If we develop materials in Setswana, you will find that people say in Kimberley, or areas outside the Hurutsi, look at those materials and say: 'Ah, this isn't proper Setswana, this isn't my Setswana, this is Hurutsi Setswana'. And it's true of all our languages - isiXhosa, isiZulu, whatever you would like to mention. There are in some instances quite significant variations that are considered unacceptable by other speakers of the same language.

Some publishers use this argument to justify their decision to limit publishing in African languages. Others however, do not consider linguistic variation to be a problem (see Ngwaru \& Edwards, 2011). ${ }^{6}$

Writers are also acutely aware of these issues, often heightened through discussions around translation. The role of translation in establishing the norms for children's writing should not be underestimated, particularly since many of those involved in translation also write for children. Some of the tensions we detected can be traced to complex relationships between linguists and 
educators. Not surprisingly perhaps, publishers have often turned to university departments of African languages for expert advice. In many cases, however, the experts in question know little about children's stories and favour highly literary language which may be inappropriate for the target audience. Two of writers working in a team on a retelling of a traditional tale expressed frustration at the insistence of a more experienced colleague with a background in linguistics on the use of the subjunctive and other markers of formality:

She certainly knows the language, how it works. So sometimes she will say: the word order is not right, this is maybe how we should be writing it. Whereas we came from the story side. We know the stories, we know how young children learn.

There was too much structure, too formal... I didn't need to know about the syntax.

In sum, there is a shortage of writers with the skills to produce successful stories for children; and the linguistic challenges associated with a newly emergent genre in African languages are significant.

\section{Capacity building initiatives}

Given the recognition that African language writers are in short supply, what is being done to build capacity? South African initiatives, often mirrored elsewhere in Africa, are based around two main areas of activity: writing competitions and workshops.

\section{Writing competitions}

Two pan-African literary awards - the Golden Baobab and the Noma - invite submissions from children's writers. The Golden Baobab specifically targets children's writers but requires stories should be in written in English. In contrast, the Noma Award (1980-2009) included writing for both adults and children and encouraged the use of African languages. During the 19-year life span of the award, books written in Afrikaans, Arabic, Gikuyu, Hausa, Ndebele, Shona, Swahili and Yoruba were among those cited for Special Commendation or Honorable Mention, although the largest numbers of successful entries were in English and other European languages. 
More local competitions also offer a useful mechanism for widening the net to reach new and aspiring authors. Publishers, for instance, use awards both to generate new books via the submission of manuscripts and also to provide an incentive to write. Although, for reasons already explored, the quality of entries tends to be poor, they serve a useful function by making explicit what publishers seek in materials for children. An editor with extensive experience of African language publishing, explains the challenges thus:

People don't know how to put a portfolio together... We'll get submissions for things which are incredibly inappropriate for us. Why? People don't know when you are submitting to a publishing house that you need to go to a website. There is a lack of understanding of how submission works. You need to go to the book shop and see what books that publisher publishes and decide which one you think your material is best suited to. They don't know how to pitch.

With sponsorship from publishers, First Words in Print, one of the projects at the Centre for the Book, part of the National Library of South Africa, was among the first to use writing competitions as the starting point for developing new books for distribution to children. Similarly, Room to Read, an NGO operating in South Africa and Zambia that sets up libraries in schools, uses competitions, publicized through libraries, local community newspapers, schools and word of mouth, to source new material in African languages. The first year generated some 220 manuscripts, of which 14 were shortlisted and five ultimately selected for publication.

Information on other regional or local awards is hard to locate but they undoubtedly exist. One such example, the Golden Kuraz - a children's book award offered by the NGO Ethiopia Reads rewards literary excellence and encourages the writing and publishing of high-quality children's books. Children, too, are potential authors. Pupils in the primary schools served by the Children's Book Project for Tanzania are invited to create their own big books; the best entry is published by the project.

\section{Workshops}


Workshops are a common form of support for writers in many other African countries. The Children's Book Project in Tanzania, for instance, has trained close to 3000 writers, though currently the main emphasis is on support for Regional Writers' Associations, the National Reading Association and the Illustrators Association.

Workshops rely on sponsorship and, in most cases, on outside expertise. This arrangement is sometimes problematic. Ambatchew (2004), for instance, describes a one-week workshop funded by a German Cultural Institute and delivered in English even though only two of the participants had previously written children's stories in the language.

In South Africa, the Centre for the book is Cape Town is an important hub for the development of local writing and emerging writers in all languages and genres. Various other groups also organize workshops, including individual publishers, and NGOs. For instance, as part of the Culture of Reading project, PRAESA held a 2 week long writers and illustrators workshop in 2002, which led to the publication by New Africa Books of 6 New Africa Stories, which are still in print in 11 languages (Bloch 2005). In a similar vein, Room to Read holds writing workshops with the authors shortlisted in their competitions to help develop their writing skills. Like competitions, workshops usually have two main aims: to generate stories for publication; and to make potential authors and illustrators more aware of what is involved in producing a story of publishable quality.

The authors we interviewed reported that they had found the workshops very beneficial, talking in terms of their increased confidence and the special contribution they felt able to make as African language writers with easy access to situations and experiences meaningful for African children. They particularly enjoyed the opportunities for sharing and feedback. Typical comments included:

When you come to a workshop like this there is an opportunity to start putting your ideas on paper. Now there is something pushing you to produce, but when you are sitting at home there's no push for you to do it.

[Taking part in workshops] told me that I am a writer. I just didn't realise that I could write... Everyone was talking about the power of writing. It makes you feel that this is something you have to do. It's a must. I feel very motivated. 
But while workshops are a valuable tool in helping nurture writers, questions remain concerning sustainability. Workshops are a useful starting point but authors need ongoing support. The emergence of writers' associations throughout the region is a useful development in this respect, though these tend to focus on European languages.

This is clearly a very complex issue, not only in an African context but also more generally: few authors are able to make a living from their writing. Authors clearly need assistance in developing their craft; they also need financial support in reaching their readership. Two South African initiatives - the Community Publishing Project (CPP) at the Centre for the Book and the Indigenous Publishing Programme run by the South African Book Development Council (SABDC) address this issue. Successful applicants to CPP not only receive mentoring from editors at a leading publishing house but also a grant to cover the costs of a small print run. Money generated from the sales of the books can be put towards a second edition, or financing a new book. By working as small publishers, writers come to understand the relationships between the various actors in the book value chain and the critical importance of marketing and distribution.

CPP is open to writers in all official languages, although growing numbers are submitted in African languages. However, IPP, which is open to South-African-owned and -controlled publishing companies, focuses specifically on the nine African languages. It aims 'to increase indigenouslanguage publishing and to support the ongoing production of South-African-authored books in local languages' (SABDC, 2009).

\section{Discussion}

Two developments are stimulating the growth of African language publishing for children. The first is the international movement towards a more holistic approach to the teaching of reading, which places the emphasis on reading as an enjoyable activity. This trend requires a shift in focus from textbooks to real books designed to engage readers' interest and attention. The second concerns the growing interest across the continent in mother tongues-based bilingual education as a tool in 
making content more accessible to children and in improving outcomes. These developments are creating a demand for African language reading materials and new opportunities for indigenous authors.

Although the importance of real books is widely recognized, former colonial languages continue to dominate the catalogues of both multinational and indigenous publishing houses. Khorana (1998: 2) suggests a number of reasons why this should be the case:

They have become part of the educational, publishing and government infrastructure: they get a wider audience for ideas among the educated elite both within and outside the country; they are necessary to maintain diplomatic, trade, and other international contacts; they provide a uniformity in internal communication amid the cultural and linguistic diversity of African nations; they make publishing more economically viable because of the multilingual population and lack of sufficient readership in any one language.

Such arguments, however, can easily be countered. First, most Africans have easy access only to local languages and are therefore disenfranchised by the exclusive use in education of the former colonial languages. Second, at the international level, there is a clear correlation between the continued use of the mother tongue and educational success (Ramirez et al., 2001; Collier \& Thomas (2003). Third, claims concerning the importance of an international language for internal and external communication imply that the use of local languages excludes the need for a language of wider communication. Those wishing to promote African languages, however, recognize the importance of both local and international languages. Finally, it can be argued that claims of economic viability are shortsighted because they fail to take into account of the enormous costs associated with school dropouts (Alexander 2001, Heugh, 2007).

In spite of the common assumption that writing for children is easier than writing for the adult market, the technical and creative challenges in crafting a successful book are considerable. There is, however, no shortage of initiatives to support and encourage aspiring writers - from competitions to workshops. 
Writers' workshops are often one-off events facilitated by outside experts. Yet while outsiders may understand the ingredients of successful stories for children, they often lack an appreciation of the cultural and linguistic issues in writing in African languages. Workshops also raise issues of sustainability. Aspiring authors need ongoing editorial support. A constant refrain from the publishers and editors interviewed was the poor quality of both commissioned work and stories submitted to competitions. Tensions between editors and authors are common, exacerbated by the inexperience of authors who fail to understand that repeated revisions are a normal part of the writing process. Pellowski's (1980) suggestion that workshops should include opportunities for participants to view authors' 'step-by-step efforts to achieve just the right language' through the numerous revisions of a manuscript makes a constructive contribution to this debate.

One obvious way forward is through collaborations, such as the writing response partnership which has emerged between two of the Xhosa speakers working on the Pinocchio story:

When somebody listens to your [writing], they can spot what is not working. We sometimes say to each other: is this how children talk? We then read it again. We do that often and it works better in the end. It sounds more natural. My partner knows how stories work, she knows what is not natural. Sometimes she says: how do you say it and then I will say it in Xhosa and then she will say: 'Yes!'

Ambatchew (2004) describes a similar approach adopted by Writers for Ethiopian Children (WEC), a group of experienced and inexperienced, national and international writers with a dual aim: to produce culturally appropriate reading materials for Ethiopian children; and to empower participants to realize their creative potential. Other initiatives that deserve attention are the materials development option on the PANMAPAL course developed at the University of Cape Town and interest in Bible Literacy Kenya to develop model collections of successful books for children.

Discussions of ways forward, however, need to be seen in the context of sustainability and the complex socio-economic issues which determine the priorities of the publishing industry. As Ambatchew (2011) points out: "If writing really paid then there would be more writers and if audiences could afford the buy more expensive books then the publishers could advertise them more". 


\section{Conclusion}

We set out to answer three main questions. Given the paucity of statistics on publishing, the answer to the first of these -the nature and extent of African language publishing for children - is necessarily partial. We can, however, make some tentative observations. While availability varies from one country to another, there is none the less evidence of growing interest in the publication of real books for children in local languages. In many cases, the main thrust comes from NGOs concerned with literacy and book promotion; in all cases, the number of titles available is constrained by funding and falls short of actual need.

In answer to our second question, the main challenges for writing for children in African languages are two fold: aspiring authors need to understand the ingredients for successful children's books; they also need sensitivity to negotiate the linguistic challenges associated with a newly emergent genre in African languages. Very few aspiring authors meet either criterion.

This leads us to the third question: What measures are being taken to support authors wishing to write for children in African languages? The most common forms of support are writing competitions and writing workshops, often offered by publishers interested in generating stories for publication. While such initiatives - and particularly the writing workshops - are to be commended, they are also problematic: often they are reliant on external funding and expertise and offer only temporary solutions. It is important to remember how demotivating the quest for publication can be. More long-lasting ways forward need to be found, in the form of writers' associations, writing response partnerships and ongoing mentoring from more experienced writers and editors. In short, as one of the workshop participants' commented: 'I am learning these things by doing, by looking at edited [material], experienced writers and translators'.

Most authors can only aspire to supplement their incomes; very few are able to make a living from their efforts. Yet the desire to tell a story and to reach a wider audience is very powerful. As Larson (2001: 110) laments: "It has never been a question of a lack of writers on the African continent; it has only been a lack of dedicated publishers." 


\section{Acknowledgements}

We wish to thank the Leverhulme Trust which funded the Interdisciplinary Perspectives on African Language materials for Children Project, the Stories Across Africa project, the Early Literacy Unit at PRAESA.

\section{References}

Abebe, T.\& Lemma, S. (1997) Assessment of Children's Books in Addis Ababa: Needs and Prospects for Publication. Addis Ababa: Forum of Street Children.

Achebe, C. (1975) The African writer and the English Language. Retrieved from: http:chisnell.com/APEng/BackgroundNotes/Achebe/tfasubaltern.rtf

Alexander, N. (2001) Language policy, symbolic power and the democratic responsibility of the post-aparheid university. D.C.S.Oosthuizen Memorial Lecture delivered at Rhodes University 9 October 2001.

Alexander, N. (ed.) (2005) Mother Tongue-based Bilingual Education in Southern Africa: the Dynamics of Implementation. Cape Town: PRAESA.

Ambatchew (2004) Challenges in Publishing Coocooloo. Paper presented at the 29th IBBY World Conference, CapeTown 2004.

Ambatchew, M.D. (2004) The Effect of Primary English Readers on Reading Skills in Ethiopia. PhD Dissertation University of Pretoria. Pretoria. 
Ambatchew, M.D. (2005) Implications of the Convention of the Rights of the Child For Ethiopian Children's Literature. Paper presented at a workshop conducted by the Ethiopian Writer's Association Held at The Russian Cultural Centre.

Ambatchew, M.D. (2007) Improvements in the Arena of Ethiopian Children's Literature. Paper resented at a workshop on Ethiopian Children's Literature of FSCE. Addis Ababa.

Ambatchew, M.D. (2010) International Communities Building Places for Youth Reading.

In S. Wolf, K. Coats, P. Enciso, \& C. Jenkins (eds), Handbook of Research on Children's and Young Adult Literature. London: Routledge, pp.430-8.

Ambatchew, M.D. (2011) Personal communication.

Baker, C. (2011) Foundations of bilingualism and bilingual education. Clevedon: Multilingual Matters.

Bloch C 1999 Literacy in the early years: teaching and learning in multilingual early childhood classrooms. International Journal of Early Years Education, 7 (1): 39-59.

Bloch,C. (2000) Don't expect a story: young children's literacy learning in South Africa. Early Years: An International Journal of Research and Development 20 (2): 57-67.

Bloch, C. \& Alexander, N. (2003) 'Aluta continua: The relevance of the continua of biliteracy to South African multilingual schools'. In N. Hornberger (ed.) Continua of biliteracy: An Ecological Framework for Educational Policy, Research and Practice in Multilingual Settings. Clevedon: Multilingual Matters.

Bloch, C. (2005). Building bridges between oral and written language: Facilitating reading opportunities for children in Africa. In N. Alexander (Ed.), Mother tongue based bilingual education in southern Africa: The dynamics of implementation. Frankfurt am Main: Multilingualism Network, pp. 69-82. 
Bloch,C. (2006) Theory and Strategy for Early Literacy Learning in Contemporary Africa with Special Reference to South Africa. PRAESA Occasional Paper No.25. Cape Town: PRAESA.

Clark, C. \& Rumbold, K. (2006) Reading for Pleasure: A Research Overview.London, National Literacy Trust. Retrieved from: www.literacytrust.org.uk/Research/readpleasure.html.

DAC (Department of Arts and Culture)(2008) Catalogue of South African Children's Literature. Pretoria: DAC.

Dils, T. (1998) You can write children's books. Writer's Digest Books, 1998

Dollerup, C. (2003) Translation for reading aloud. Meta 48, 1-2: 81-103.

Edwards, V. (2009) Learning to be literate: multilingual perspectives. Bristol: Multilingual Matters.

Edwards, V. \& Ngwaru, J.M. (2010) African language publishing for children: where next?www.ncll.org.uk/50_research/30_research_papers/AfricanLangPublishing.pdf

Edwards, V. \& Ngwaru, J.M. (2011) African language publishing for children: issues for translators. International Journal of Bilingual Education and Bilingualism

Edwards, V. \& Ngwaru, J.M. (forthcoming) African language publishing for children: issues for publishers.

Gregorio, P. (2001) African literature. In B. Cullinan \& D. Person (eds) The Continuum Encyclopedia of Children's Literature. London: Continuum, pp 13-15.

Guzula, X., Maseko, P. \&Nkence, N. with Schermbrucker, R. (2007) The Adventures of Pinocchio.Cape Town: PRAESA, New Africa Books.

Heugh, K. (2006) Financing mother tongue and bilingual education. In H. Alidou, A. Boly, B. BrockUtne, Y.S. Diallo, K. Heugh, K. and H.E. Wolff (2006) Optimizing Learning and Education in Africa-the Language Factor: A Stock-Taking Research on Mother Tongue and Bilingual Education in Sub-Saharan Africa. Retrieved from: www.adeanet.org 
Heugh, K. (2007) 'Language and literacy issues in South Africa'. In N. Rassool(ed.)(2007) Global Issues in languages, education and development: perspectives from postcolonial languages. Clevedon: Multilingual Matters, pp.187-217.

IMF (International Monetary Fund)(2010) Economic Outlook Databases, www.imf.org/external/pubs/ft/weo/2010/02/weodata/index.aspx).

Khorana, M (1998) Children's publishing in Africa: can the colonial past be forgotten? In M. Khorana (ed.) Critical perspectives on Post-colonial African children's and young adults literature. Greenwood Press, pp. 2-13.

Kruger, H. (2009) Language-in-education policy, publishing and the translation of children's books in South Africa. Perspectives 17, no. 1: 33-61.

Larson, C.R (2001) The Ordeal of the African Writer. Zed Books: London.

Lewis, P. (2009) Ethnologue: Languages of the World. Sixteenth Edition. SIL International

O'Sullivan, E. (2005) Comparative children's literature. Abingdon: Routledge.

OECD (Organisation for Economic Co-operation and Development) (2008) Reviews of national policies for education: South Africa. Paris: OECD.

Oittinen, R. (2003) Where the wild things are: translating picture books. Meta 48, nos. 1-2: 128141.

Osa, O. (2007) African children's and youth literature - then and now. Retrieved from: http://www.thefreelibrary.com/African+children\%27s+and+youth+literature-then+and+now.-a0192351989

Osaki, L.T. (2004) African Children's Literature. Retrieved from: www.uflib.ufl.edu/cm/africana/children.htm

Owu-Ewie, C. (2006)The Language Policy of Education in Ghana: A Critical Look at the English-Only Language Policy of Education. In J. Mugane, J. Hutchison \& D. Worman (eds) Selected Proceedings of the 35th Annual Conference on African Linguistics: African Languages and 
Linguistics in Broad Perspectives. Somerville, MA: Cascadilla Proceedings Project 2006, pp.76-85.

PASA (Publishers Association of South Africa). 2007/2008/2009. Writing in Nine Tongues. Cape Town: PASA.

Pellowski. A. (1980) Made to measure: children's books in developing countries. Paris: UNESCO.

Prah, K. (2009) Mother Tongue Education in Africa for Emancipation and Development: towards the intellectualization of African Languages. In B. Brock-Utne \& I. Skattum (eds) Languages and education in Africa: a comparative and transdisciplinary analysis. Oxford: Symposium Books, pp. 83-104.

Shepard, A. (2000) The Business of Writing for Children: An Award-Winning Author's Tips on Writing Children's Books and Publishing Them, or How to Write, Publish, and Promote a Book for Kids. Slough: Shepard Publications.

Tesfaye G-M. (2004) Challenges in Publishing Children's literature in Ethiopia. Mimeo.

Tesfaye G-M. (2005) Publishing Children's Literature in Ethiopia: Prospects and Challenges. Paper presented at the Institute of Ethiopian Studies conference on Publishing in Ethiopia. Addis Ababa.

Trudell, B. 2010. When 'Prof' speaks, who listens? The African elite and the use of African languages for education and development in African communities. Language and Education 24, no. 4: $337-52$.

UNESCO (2005) Literacy for life.EFA Global Monitoring Report 2006. Paris: UNESCO.

waThiong'o, N. (1986)Decolonising the Mind: The Politics of Language in African Literature. London: Heinemann

Wafawarowa, B. (1996) Intellectual Property Rights and Knowledge Production in Africa Retrieved from:

www.iccwbo.org/uploadedFiles/ICC/policy/intellectual_property/pages/BrianWafawarowa.d oc. 
Weaver, N. (2010) Guest Blogger: Nicole Weaver, Author of Marie and Her Friend the Sea Turtle.

Book blogs: The Children's and Teens' Book Connection.

http://bookblogs.ning.com/profiles/blogs/childrens-author-nicole-weaver?xg_source=activity

\footnotetext{
${ }^{1}$ Mother tongue-based bilingual education is the term preferred in South Africa, and is also used increasingly in other African countries.

${ }^{2}$ Stories across Africa was initiated and has been co-ordinated by the Early Literacy Unit at PRAESA. It is a core project of the African Academy of Languages (ACALAN).

${ }^{3}$ trade market

${ }^{4}$ By 'difficult to access' we mean papers and reports not available to download from the Internet or to obtain copies outside the country of origin.

5 'Nine tongues' refers to the languages recognized in the 1996 South African constitution other than English and Afrikaans.
} 